\title{
Biological aspects of Cyclocephala tucumana Brethes, 1904 and Cyclocephala melanocephala (Fabricius, 1775) (Coleoptera: Scarabaeidae)
}

\author{
Gerson Aler de Lima Nogueira ${ }^{1}$, Sérgio Roberto Rodrigues ${ }^{1,2}$ \& Elison Floriano Tiago ${ }^{1}$ \\ ${ }^{1}$ Departamento de Entomologia, Universidade Estadual de Mato Grosso do Sul - UFMS, \\ Rod. Aquidauana/CERA, Km 12, CEP 79200-000, Aquidauana, MS, Brasil \\ ${ }^{2}$ Corresponding author: Sérgio Roberto Rodrigues, e-mail: sergio@uems.br
}

NOGUEIRA, G.A.L., RODRIGUES, S.R. \& TIAGO, E.F. Biological aspects of Cyclocephala tucumana Brethes, 1904 and Cyclocephala melanocephala (Fabricius, 1775) (Coleoptera: Scarabaeidae). Biota Neotrop. 13(1): http://www.biotaneotropica.org.br/v13n1/en/abstract?article+bn01713012013

\begin{abstract}
The studies were conducted on the biological aspects of Cyclocephala tucumana Brethes, 1904 and C. melanocephala (Fabricius, 1775) in Aquidauana, MS, Brazil. From January to December 2009 a light trap was installed to make collections of adults of C. tucumana and from January 2010 to February 2011 for collections of adults of $C$. melanocephala, at the experimental farm of the Universidade Estadual de Mato Grosso do Sul. Adults were maintained in plastic containers with soil and complete plants of Brachiaria decumbens Stapf cv. Basilisk to oviposition and start biological studies. Adults of $C$. tucumana were collected from September to November in the field; the embryonic period lasted on average 14.7 days, and the first, second and third larval instars lasted 47.7, 66.1 and 78.6 days, respectively. Pre-pupa and pupa phases lasted 98.2 and 15.1 days, respectively, and longevity of the adults was 13.3 days. From the egg to adult stage of $C$. tucumana was a period of average 211.2 days. Adults of C. melanocephala were collected from September to October 2010 and February 2011. The embryonic period lasted 17.8 days, and larvae in the first, second and third instars lasted 22.3, 21.0 and 27.0 days, respectively. The pre-pupa stage lasted 11.3 days and pupa phase lasted 13.3 days. The longevity of adults was 26 days, and the cycle from egg to adult lasted 113 days.
\end{abstract}

Keywords: life cycle, Cyclocephalini, Dynastinae, insects of the soil.

NOGUEIRA, G.A.L., RODRIGUES, S.R. \& TIAGO, E.F. Aspectos biológicos de Cyclocephala tucumana Brethes, 1904 e Cyclocephala melanocephala (Fabricius, 1775) (Coleoptera: Scarabaeidae). Biota Neotrop. 13(1): http://www.biotaneotropica.org.br/v13n1/pt/abstract?article+bn01713012013

Resumo: Foram desenvolvidos estudos sobre os aspectos biológicos de Cyclocephala tucumana Brethes, 1904 e C. melanocephala (Fabricius, 1775) em Aquidauana, MS. Foi instalada uma armadilha luminosa de janeiro a dezembro de 2009 para obter adultos de C. tucumana e de janeiro de 2010 a fevereiro de 2011 para obter adultos de C. melanocephala, na fazenda experimental da Universidade Estadual de Mato Grosso do Sul. Adultos foram mantidos em recipientes de plástico, contendo solo e plantas de Brachiaria decumbens Stapf cv. Basilisk, para oviposição e início dos estudos biológicos. Os adultos de C. tucumana foram coletados de setembro a novembro no campo, o período embrionário durou em média 14,7 dias, e o primeiro, segundo e terceiro instar larval duraram 47,7, 66,1 e 78,6 dias, respectivamente. As fases de pré-pupa e pupa duraram 98,2 e 15,1 dias, respectivamente, e a longevidade dos adultos foi de 13,3 dias. A fase de ovo a adulto de C. tucumana durou em média 211,2 dias. Os adultos de C. melanocephala foram coletados em setembro e outubro de 2010 e em fevereiro de 2011. O período embrionário durou 17,8 dias, as larvas no primeiro, segundo e terceiro instar duraram 22,3, 21,0 e 27,0 dias, respectivamente. A fase de pré-pupa durou 11,3 dias a pupa durou 13,3 dias. A longevidade dos adultos foi de 26 dias, e o ciclo de ovo a adulto durou 113 dias.

Palavras-chave: ciclo de vida, Cyclocephalini, Dynastinae, insetos de solo. 


\section{Introduction}

According to Ratcliffe \& Cave (2002) there are approximately 300 known species in the American genus Cyclocephala Dejean, 1821. In the various regions of Brazil, 83 species of the genus Cyclocephala are registered (Morón 2004).

In the city of São Gabriel da Cachoeira, AM, Brazil, Andreazze \& Mota (2002) used light traps for attract Cyclocephala guianae Endrödi, 1969, C. lunulata Burmeister, 1847, C. simulatrix Hohne, 1923, and three Cyclocephala spp.. Andreazze \& Fonseca (1998) collected 18 species of Dynastinae in Itacoatiara, AM with light traps, where nine species were of the genus Cyclocephala, identified as C. colasi Endrödi, 1964, C. bicolor Castelnau, 1840, C. affinis Endrödi, 1966, C. hardyi Endrödi, 1975, C. testacea Burmeister, 1847, C. mecynotarsis Hohne, 1923, C. acellata Burmeister, 1847, C. variabilis Burmeister, 1847 and C. verticalis Burmeister, 1847.

Andreazze (2001) collected 11 species of Cyclocephala in the National Park of Jaú, AM using light traps, being identified as C. colasi Endrödi, 1964, C. bicolor Castelnau, 1840, C. guianae Endrödi, 1969, C. hardyi Endrödi, 1975, C. paraflora Martinez, 1978, C. testacea Burmeister, 1847 and C. verticalis Burmeister, 1847, as well as four species identified only at the genus level.

In an area of Eucalyptus grandis in Santa Bárbara, MG, Brazil, Freitas et al. (2002) obtained Cyclocephala laminata Burmeister, 1847 with a light trap. Nine species of Cyclocephala were collected by Ronqui \& Lopes (2006) in Tamarana, PR, Brazil with light traps, which were identified only at the genus level. In five locations of Paraná, in southern Brazil, Riehs (2006) used light traps to collect C. variabilis Burmeister, 1847, C. clarae Höhne, 1923, C. suturalis Ohaus, 1911, C. signaticollis Burmeister 1847, C. paraguayensis Arrow, 1903 and C. variolosa Burmeister, 1847.

In 23 municipalities in the region of Planalto, Rio Grande do Sul, Brazil, Cherman (2011) sampled larvae of Scarabaeidae in different cultures, and identified Cyclocephala flavipennis Arrow, 1914, C. modesta Burmeister, 1855, C. putrida Burmeister, 1847, C. tucumana Brethes, 1904 and C. metrica Steinheil, 1874. Salvadori $\&$ Pereira (2006) found that $C$. flavipennis feeds on decaying organic matter and Salvadori (1999) reported that this species, even at the densities sampled of approximately 80 to 100 larvae $/ \mathrm{m}^{2}$ in the field do not cause damage to crops.

In the Midwest region of Brazil, the occurrence of C. melanocephala (Fabr., 1775) was registered in sunflower crop (Camargo \& Amabile 2001). In Aquidauana, MS, Brazil, Rodrigues et al. (2010) collected adults of $C$. verticalis with a light trap. In soybean fields of Macaraju, MS, Brazil, Santos \& Ávila (2007) encountered larvae of C. forsteri Endrödi, 1966 feeding of roots of this legume. In a sugar cane field in Sidrolândia, MS, Brazil, Coutinho (2010) found larvae of $C$. verticalis and $C$. forsteri feeding of the root system. Cyclocephala verticalis was found feeding of roots of Acrocomia aculeata (Puker et al. 2009).

According to observations of Prance \& Arias (1975) in the region of Manaus, AM, adults of Cyclocephala hardyi were encountered in flowers of Victoria amazonica, where they were frequently encountered feeding on and cross pollinizing this plant species. In experiments conducted in the municipalities of Goiânia and Vila Propício in Goiás, Brazil, Cavalcante et al. (2009) found as visitors to flowers araticum (Annona crassiflora) (Annonaceae), Cyclocephala atricapilla Mannerheim, 1829, Cyclocephala latericia Hohne, 1923 and Cyclocephala octopunctata Burmeister, 1847, being considered as important pollinators.

In Brazil, C. melanocephala is reported as occurring in various states including BA, ES, MG, MT, PE, RJ, RS and SC, while the occurrence of C. tucumana is registered in PR and RS (Camargo \& Amabile 2001, Morón 2004, Cherman 2011). Information on biological aspects of the Cyclocephala species occurring in Brazil are scarce. Based on the lack of information studies were developed with the objective of understanding the biological aspects of C. tucumana and C. melanocephala in Aquidauana, MS, Brazil.

\section{Materials and Methods}

The study was developed at the Universidade Estadual de Mato Grosso do Sul (UEMS), in the municipality of Aquidauana, MS. Adults of Cyclocephala tucumana and Cyclocephala melanocephala were collected with a "Luiz de Queiroz" light trap installed daily between the pasture and field areas, at 6:00 PM and collected at 6:00 AM on the following day. Adults of C. tucumana were collected from January to December 2009, and C. melanocephala from January 2010 to February 2011.

During the periods of trapping, adults of C. tucumana and C. melanocephala were separated and quantified in the laboratory for observation of behavior and the oviposition period, as was performed by Rodrigues et al. (2010) when studying Cyclocephala verticalis.

Adults were maintained in plastic recipients $(20 \times 5 \times 30 \times$ $12 \mathrm{~cm}$ in depth) containing soil and complete plants of Brachiaria decumbens Stapf cv. Basilisk (Poaceae) so that the insects would mate and oviposition. Recipients were covered with a voile fabric that allowed plant growth and prevented escape of the insects.

Containers were inspected daily for acquisition of eggs and initiation of the biological study. When encountered, eggs were measured, transferred to Petri dishes containing sieved soil, moistened and maintained in laboratory conditions $\left(26^{\circ} \mathrm{C}, 12 \mathrm{~h}\right.$ photoperiod). Periodically (every two days) the plates were observed and larvae that hatched had their head capsule measured and durations verified, followed by transfer to individual $500 \mathrm{~mL}$ plastic containers containing soil and $B$. decumbens where plants were replaced weekly to monitor development and change of instar. When larvae reached the pre-pupae phase they no longer fed, but larvae remained on the soil at the surface of the recipient where they remained until reaching the adult phase (adapted from Rodrigues et al. 2010).

Biological variables evaluated for both species were the duration of the embryonic period, duration of the larval and pupal periods, and also longevity of the adults.

Specimens were deposited in the entomology collection of the Universidade Estadual de Mato Grosso do Sul, in Aquidauana, MS, Brazil.

\section{Results}

\section{Cyclocephala tucumana}

Regarding population dynamics of adults of C. tucumana was verified that these were found in the field during a short period of time, where 34 adults were collected in September $(28.1 \%)$, in October 52 (43.0\%) and in November 35 (28.9\%) (Figure 1).

When dissecting some of the females it was found that in September there was an average of 10.5 eggs $(4-14)(n=6)$ per female, in October $10.8(5-15)(n=6)$ and November $6.5(1-12)(n=6)$. Thus, it can be inferred that the period in which females are encountered in flight in the field is also the oviposition period.

Eggs of C. tucumana were found individually at the bottom of recipients where adults were maintained, protected in chambers within the soil with average dimensions of 2 to $3 \mathrm{~mm}$ in diameter $(\mathrm{n}=20)$, probably constructed with saliva from adults as well as soil. Eggs are white with average dimensions of $1.5 \times 1.7 \mathrm{~mm}(\mathrm{n}=20)$. The embryonic period of C. tucumana lasted 14.7 days (Table 2).

In the first instar larvae possess an average width of $1.4 \mathrm{~mm}$ and body length of $3.8 \mathrm{~mm}$, width of $1.4 \mathrm{~mm}$ and average weight of 
$0.0039 \mathrm{~g}$. Larvae of the second instar had an average head capsule width of $2.1 \mathrm{~mm}$, body length of $10.3 \mathrm{~mm}$, width of $2.1 \mathrm{~mm}$ and weight of $0.0485 \mathrm{~g}$ (Table 1).

The third instar larvae presented head capsule width of $3.1 \mathrm{~mm}$ and body length of $16.6 \mathrm{~mm}$, width of $3.1 \mathrm{~mm}$, and weight of $0.1649 \mathrm{~g}$ (Table 1). From the first to third instar, it was observed that larvae significantly increase in size, showing an increase of 4.4 times its length and 2.2 times its width (Table 1). With regards to larvae weight, from the first to third instar the weight increased from $0.0039 \mathrm{~g}$ in the first instar to $0.1649 \mathrm{~g}$ in the third instar, an increase of roughly 42.2 times.

Larvae remained in the first instar for 47.7 days (Table 2). The second instar stage lasted 66.1 days and third instar phase 78.6 days (Table 2). The pre-pupal stage lasted 98.2 days on average, thus, duration of the larval stage was on average 191.9 days (Table 2).

When reaching the pre-pupa stage the larvae acquired a white color and no longer feed, and when transforming into pupae prepare a chamber in the soil where they remain protected. Normally chambers where the pupae remained were at the bottom of the recipients. Pupae presented average dimensions of $9.2 \mathrm{~mm}$ in length and in $4.3 \mathrm{~mm}$ width (Table 1), and the average duration was 15.1 days on average (Table 2).

Upon reaching adult hood, it was observed that the average longevity was 13.3 days (Table 2). The adults measure $9.1 \mathrm{~mm}$ long by $4.1 \mathrm{~mm}$ in chest width $(\mathrm{n}=10)$. They have light brown thorax and elytra. The head is dark tending to black in the frontal region between the eyes, and on the clypeus the color is dark brown. The biological cycle was completed with an average of 211.2 days, which allows for the formation of one generation per year, characterizing the species as univoltine.

\section{Cyclocephala melanocephala}

Adults of C. melanocephala were encountered in small quantity, finding two (28.6\%) adults in September and five (71.4\%) in October of 2010, and only one adult (12.5\%) was obtained in February of 2011. Flight activity in the field thus occurred during a very short period (Figure 2).

In the rearing recipients eggs were encountered, which were isolated in chambers constructed of soil and saliva which have

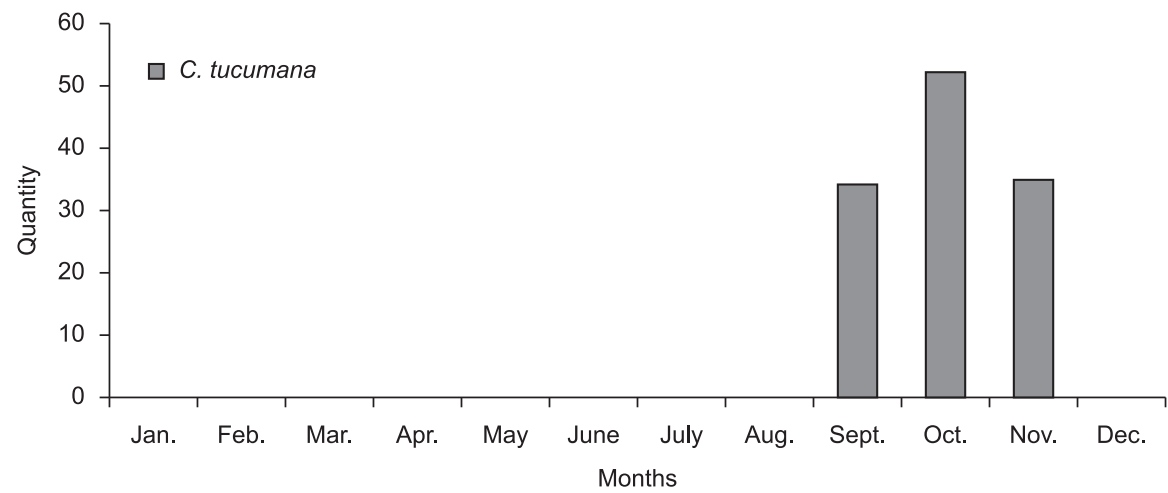

Figure 1. Number of adults of Cyclocephala tucumana collected in trap light from January to December 2009, in Aquidauana, MS.

Table 1. Means $( \pm \mathrm{SE})$ of the length and width of the development stages of Cyclocephala tucumana in the laboratory $\left(26 \pm 1{ }^{\circ} \mathrm{C}, 12 \mathrm{~h}\right.$ photoperiod).

\begin{tabular}{|c|c|c|c|c|c|c|}
\hline \multirow{2}{*}{ Stage } & \multicolumn{3}{|c|}{ Length (mm) } & \multicolumn{3}{|c|}{ Width (mm) } \\
\hline & Mean \pm SE & $\mathbf{N}$ & Amplitude & Mean \pm SE & $\mathbf{N}$ & Amplitude \\
\hline Egg & $1.7 \pm 0.03$ & 210 & $1.4-2.2$ & $1.5 \pm 0.02$ & 210 & $1.0-2.0$ \\
\hline \multicolumn{7}{|l|}{ Larval } \\
\hline $1^{\text {st }}$ instar & $3.8 \pm 0.05$ & 155 & $3.0-4.0$ & $1.4 \pm 0.01$ & 155 & $1.2-1.4$ \\
\hline $2^{\text {nd }}$ instar & $10.3 \pm 0.68$ & 98 & $0.9-14.0$ & $2.1 \pm 0.02$ & 98 & $1.8-2.6$ \\
\hline $3^{\text {rd }}$ instar & $16.6 \pm 0.47$ & 81 & $13.0-21.0$ & $3.1 \pm 0.02$ & 81 & $2.85-3.25$ \\
\hline Pupal & $9.2 \pm 1.22$ & 23 & $1.1-12.9$ & $4.3 \pm 0.58$ & 23 & $0.47-6.5$ \\
\hline Adult & $9.2 \pm 0.08$ & 17 & $8.8-10$ & $3.9 \pm 0.03$ & 17 & $3.7-4.1$ \\
\hline
\end{tabular}

Table 2. Duration (mean $\pm \mathrm{SE}$ ) of the development stages of Cyclocephala tucumana in the laboratory $\left(26 \pm 1{ }^{\circ} \mathrm{C}, 12 \mathrm{~h}\right.$ photoperiod).

\begin{tabular}{lcccc}
\hline \multicolumn{1}{c}{ Stage } & Duration (days) & N & Interval of variation & Viability (\%) \\
\hline Egg & $14.7 \pm 0.24$ & 210 & $9-22$ & 73.8 \\
$\quad 1^{\text {st }}$ instar & $47.7 \pm 1.69$ & 155 & $29-93$ & 63.2 \\
$2^{\text {nd }}$ instar & $66.1 \pm 2.04$ & 98 & $28-109$ & 82.6 \\
$3^{\text {rd }}$ instar & $78.6 \pm 1.77$ & 81 & $34-113$ & 66.6 \\
Pre-pupal & $98.2 \pm 2.01$ & 54 & $76-121$ & 42.5 \\
Larval duration & $191.9 \pm 0.79$ & 54 & $185-201$ & 25.7 \\
Pupal & $15.1 \pm 0.63$ & 23 & $12-23$ & 73.9 \\
Adult & $13.3 \pm 1.05$ & 17 & $8-20$ & 100 \\
Egg to adult & $211.2 \pm 9.70$ & 17 & $179-270$ & 8.1 \\
\hline
\end{tabular}


average dimensions of 9.7 to $9.75 \mathrm{~mm}$ in diameter $(\mathrm{n}=4)$. Eggs have a white color and average dimensions of $2.65 \times 2.30 \mathrm{~mm}$ (Table 3). It is possible that the chambers were constructed by females, which provide a protective environment for the egg.

The incubation period of eggs was on average 17.8 days (Table 4 ). Larvae of the first instar remained 22.3 days in this phase, in the second instar larvae remained 21.0 days and in the third instar an average of 27.0 days (Table 4 ). The pre-pupal stage lasted 11.3 days on average. Thus, larval duration was 70.7 days (Table 4).

First instar larvae of C. melanocephala had an average length of $5 \mathrm{~mm}$, weight of $0.0163 \mathrm{mg}$ and average head capsule width of 1.4 $\mathrm{mm}$. Second instar larvae had an average length of $10.7 \mathrm{~mm}$, weight of $0.0405 \mathrm{mg}$ and head capsule width of $2.45 \mathrm{~mm}$. The third instar larvae had an average length of $21.0 \mathrm{~mm}$, weight of $0.1882 \mathrm{mg}$ and head capsule width of $3.50 \mathrm{~mm}$ (Table 3 ). From the first to third instar the larvae increased 4.2 times, showing a considerable increase in their size.

Upon reaching the pre-pupae phase the insects stop feeding and remain in chambers with external average length of $32.0 \mathrm{~mm}$ and average width of $18.0 \mathrm{~mm}$, and inner average length of $22.0 \mathrm{~mm}$ and width of $14.0 \mathrm{~mm}$, constructed at the bottom of the rearing recipient. In this stage the pre-pupae have a greyish to white color.
The pupal stage lasted 13.3 days and adults had an average longevity of 26.0 days (Table 4). Pupae of C. tucumana had an average length of $12.1 \mathrm{~mm}$ and average width of $5.3 \mathrm{~mm}$, and the adults had an average length of $11.9 \mathrm{~mm}$ and average chest width of $4.9 \mathrm{~mm}$ (Table 3$)$. The elytra of adults are light brown, but the chest is red.

Duration of the egg to adult phase of $C$. melanocephala lasted 113 days on average in the laboratory, where the formation of two generations per year may be possible. In the laboratory a single moment of mating was observed when inspecting the rearing recipients, and on this occasion it was observed that copulation lasted seven minutes followed by the male remaining on top of the female for three minutes.

\section{Discussion}

The period of flight activity of two species studied was similar to other Scarabaeidae collected in the region of Aquidauana, MS, as observed by Rodrigues et al. (2008a, b, 2010).

Eggs of $C$. tucumana had dimensions similar to those of C. verticalis which measured $1.5 \times 1.8 \mathrm{~mm}$ (Rodrigues et al. 2010) and $C$. parallela with average diameter of $1.9 \mathrm{~mm}$ (Cherry 1985), however, the eggs of $C$. melanocephala are larger. Regarding the

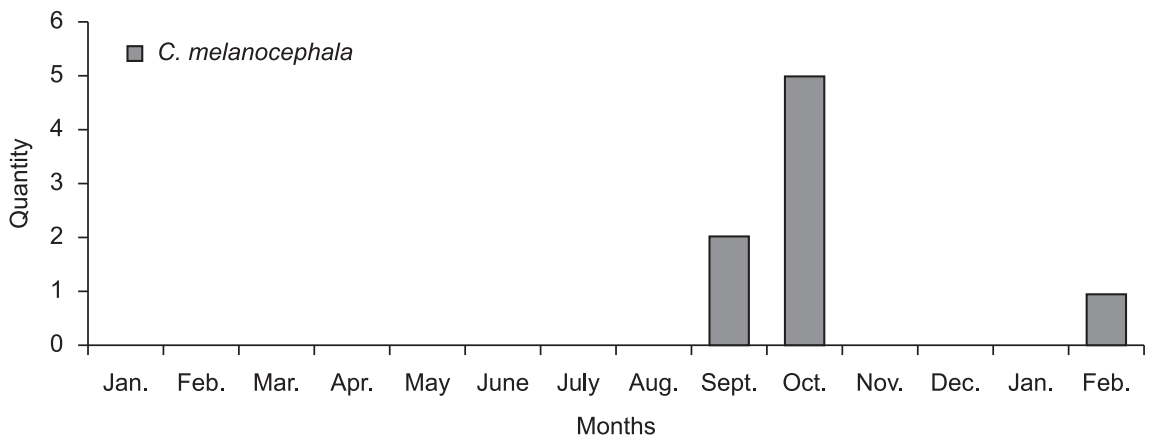

Figure 2. Number of adults of Cyclocephala melanocephala collected in trap light from January 2010 to Feberuary 2011, in Aquidauana, MS.

Table 3. Means ( \pm SE) of the length and width of the development stages of Cyclocephala melanocephala in the laboratory $\left(26 \pm 1{ }^{\circ} \mathrm{C}, 12 \mathrm{~h}\right.$ photoperiod)

\begin{tabular}{|c|c|c|c|c|c|c|}
\hline \multirow{2}{*}{ Stage } & \multicolumn{3}{|c|}{ Length (mm) } & \multicolumn{3}{|c|}{ Width (mm) } \\
\hline & Mean $\pm \mathrm{SE}$ & $\mathbf{N}$ & Amplitude & Mean \pm SE & $\mathbf{N}$ & Amplitude \\
\hline Egg & $2.65 \pm 0.07$ & 10 & $2.45-2.80$ & $2.30 \pm 0.06$ & 10 & $2.20-2.55$ \\
\hline \multicolumn{7}{|l|}{ Larval } \\
\hline $1^{\text {st }}$ instar & $5.0 \pm 0.03$ & 8 & $4.8-5.0$ & $1.2 \pm 0.03$ & 8 & $1.1-1.3$ \\
\hline $2^{\text {nd }}$ instar & $10.7 \pm 0.43$ & 6 & $9.0-11.0$ & $2.3 \pm 0.02$ & 6 & $2.20-2.35$ \\
\hline $3^{\text {rd }}$ instar & $21.0 \pm 0.45$ & 6 & $19.0-22.0$ & $3.3 \pm 0.02$ & 6 & $3.25-3.40$ \\
\hline Pupal & $12.1 \pm 0.35$ & 6 & $11.0-13.0$ & $5.3 \pm 0.14$ & 6 & $4.9-5.7$ \\
\hline Adult & $11.9 \pm 0.48$ & 6 & $9.5-12.5$ & $4.9 \pm 0.96$ & 6 & $4.2-5.0$ \\
\hline
\end{tabular}

Table 4. Duration (mean $\pm \mathrm{SE}$ ) of the development stages of Cyclocephala melanocephala in the laboratory $\left(26 \pm 1{ }^{\circ} \mathrm{C}, 12 \mathrm{~h}\right.$ photoperiod).

\begin{tabular}{lcccc}
\hline \multicolumn{1}{c}{ Phase } & Duration (days) & N & Interval of variation & Viability (\%) \\
\hline Egg & $17.8 \pm 0.20$ & 10 & $17-18$ & 80.0 \\
$\quad 1^{\text {st }}$ instar & $22.3 \pm 0.75$ & 8 & $21-24$ & 75.0 \\
$2^{\text {nd }}$ instar & $21.0 \pm 1.53$ & 6 & $19-24$ & 100.0 \\
$\quad 3^{\text {rd }}$ instar & $27.0 \pm 1.73$ & 6 & $24-30$ & 100.0 \\
Pre-pupal & $11.3 \pm 0.67$ & 6 & $10-12$ & 100.0 \\
Larval duration & $70.7 \pm 1.76$ & 6 & $68-74$ & 100.0 \\
Pupal & $13.3 \pm 0.67$ & 6 & $12-14$ & 100.0 \\
Adult & $26.0 \pm 0.58$ & 6 & $25-27$ & 100.0 \\
Egg to adult & $113 \pm 3.5$ & 6 & $112-117$ & 60.0 \\
\hline
\end{tabular}


embryonic period, C. tucumana exhibited shorter duration in this phase when compared with $C$. melanocephala.

The head capsule width of C. tucumana and C. melanocephala present similar values. However, Santos \& Avila (2007) found that the average width of the head capsule of $C$. forsteri was greater than the two mentioned species, measuring $2.49,4.18$ and $7.04 \mathrm{~mm}$ in first, second and third instar, respectively.

The larval phase of C. tucumana lasts 191.9 days, being longer than that of $C$. melanocephala which lasted 70.7 days. The larval phase of $C$. verticalis is 195.7 days (Rodrigues et al. 2010), very similar to that observed for C. tucumana.

The behavior observed for construction of chambers by pre-pupae of the two species studied was also observed by Rodrigues et al. (2010) for $C$. verticalis reared in the laboratory.

Duration of the cycle from egg to adult of C. tucumana allows for the formation of one generation per year, as observed for C. verticalis by Rodrigues et al. (2010). According to Santos \& Ávila (2007), C. forsteri completes its life cycle in one year, and according to Mondino et al. (1997), C. signaticollis Burmeister, 1847 also completes its cycle in one year.

The cycle from egg to adult of $C$. melanocephala, was similar to that observed for Anomala testaceipennis Blanchard, 1856 which required 139.4 days to complete its development (Rodrigues et al. 2008a).

The coupling behavior of $C$. melanocephala, which remained on top of the female after terminating coupling was reported by Rodrigues et al. (2010) for C. verticalis, where even after finishing copulation the male remained fixed on the female, presenting a defensive position, possibly trying to ensure fertilization of the egg with its genetic material.

\section{Acknowledgments}

The authors thank Dr. Miguel Angel Morón (Instituto de Ecología, México) for identification of C. tucumana and Dr. Fernando Zagury Vaz-de-Mello (Universidade Federal de Mato Grosso, Brazil) for identification of C. melanocephala.

\section{References}

ANDREAZZE, R. 2001. Dinastíneos (Coleoptera, Scarabaeidae, Dynastinae) do Parque Nacional do Jaú, Amazonas, Brasil. Acta Amaz. 31(3):431-435.

ANDREAZZE, R. \& MOTTA, C.S. 2002. Besouros dinastíneos (Coleoptera, Scarabaeidae, Dynastinae) de Querari, Município de São Gabriel da Cachoeira, Estado do Amazonas, Brasil. Acta Amaz. 32(4):725-727.

ANDREAZZE, R. \& FONSECA, C.R.V. 1998. Dinastíneos (Coleooptera, Scarabaeoidea, Melolonthidae) em uma área de terra firme na Amazônia Central, Brasil. Acta Amaz. 28(1):59-66.

CAVALCANTE, T.R.M., NAVES, R.V., FRANCESCHINELli, E.V. \& SILVA, R.P. 2009. Polinização e formação de frutos em araticum. Bragantia. 68(1):13-21. http://dx.doi.org/10.1590/S000687052009000100002

CAMARGO, A.J.A. \& AMABILE, R.F. 2001. Identificação das Principais Pragas do Girassol na Região Centro-Oeste. Ministério da Agricultura e do Abastecimento, Embrapa/CNPDF, Brasília, 4p. Comunicado Técnico, n.50.

CHERMAN, M.A. 2011. Análise populacional de Melolonthidae (Coleoptera) da região do Plananto do Rio Grande do Sul. Dissertação de Mestrado, Universidade Federal de Santa Maria, Santa Maria.
CHERRY, R.H. 1985. Seasonal phenology of white grubs (Coleoptera: Scarabaeidae) in Florida sugarcane fields. J. Econ. Entomol. 78(4):787-789.

COUTINHO, G.V. 2010. Aspectos biológicos e densidade de larvas de Scarabaeidae fitófagos em cultura de cana-de-açúcar, em Sidrolândia, na região central de Mato Grosso do Sul. Dissertação de Mestrado, Universidade Estadual de Mato Grosso do Sul, Aquidauana.

FREITAS, F.A., ZANUNCIO, T.V., LACERDA, M.C. \& ZANUNCIO, J.C. 2002. Fauna de Coleoptera coletada com armadilhas luminosas em plantio de Eucalyptus grandis em Santa Bárbara, Minas Gerais. Rev. Árv. 26(4):505-511.

MONDINO, E.A, LÓPEZ, A.N., ALVAREZ-CASTILlO, H.A. \& CARMONA, D.M. 1997. Ciclo de vida de Cyclocephala signaticollis Burmeister, 1847 (Coleoptera, Scarabaeidae, Dynastinae) y su relación con los factores ambientales. Elytron. 11:145-156.

MORÓN, M.A. 2004. Melolontídeos edafícolas. In Pragas de Solo no Brasil (J.R. Salvadori, C.J. Ávila \& M.T.B. Silva, eds.). Embrapa-CNPT, Passo Fundo, Embrapa-CPAO, Dourados, Fundacep Fecotrigo, Cruz Alta, p.133-166.

PRANCE, G.T. \& ARIAS, J.R. 1975. A Study of the Floral Biology of Victoria amazonica (Poepp.) Sowerly (Nymphaceae). Acta Amaz. 5(2):109-139.

PUKER, A., RODRIGUES, S.R., TIAGO, E.F. \& SANTOS, W.T. 2009. Espécies de Scarabaeidae fitófagos (Insecta: Coleoptera) associadas ao sistema radicular de Acrocomia aculeata (Jacq.) Lodd. ex Mart. (Arecaceae). Biota Neotrop. 9(3):105-109. http://dx.doi.org/10.1590/ S1676-06032009000300009

RATCLIFFE, B.C. \& CAVE, R.D. 2002. New species of Cyclocephala from Honduras and El Salvador (Coleoptera: Scarabaeidae: Dynastinae: Cyclocephalini). The Coleopt. Bull. 56(1):152-157. http://dx.doi. org/10.1649/0010-065X(2002)056[0152:NSOCFH]2.0.CO;2

RIEHS, P.J. 2006. Fenologia de algumas espécies do gênero Cyclocephala (Coleoptera, Scarabaeidae) do Leste e Centro-Oeste do Paraná, Brasil. Rev. Ciênc. Ex. Nat. 8(2):201-223.

RODRIGUES, S.R., NOGUEIRA, G.A.L., ECHEVERRIA, R.R. \& OLIVEIRA, V.S. 2010. Aspectos biológicos de Cyclocephala verticalis Burmeister (Coleooptera: Scarabaeidae). Neotrop. Entomol. 39(1):15-18. http://dx.doi.org/10.1590/S1519-566X2010000100003

RODRIGUES, S.R., PUKER, A., ABOT, A.R., BARBOSA, C.L., IDE, S. \& COUTINHO, G.V. 2008a. Ocorrência e aspectos biológicos de Anomala testaceipennis Blanchard (Coleoptera, Scarabaeidae). Rev. Bras. Entomol. 52(1):68-71. http://dx.doi.org/10.1590/S008556262008000100012

RODRIGUES, S.R., BARBOSA, C.L., PUKER, A., ABOT, A.R. \& IDE, S. 2008b. Occurrence, biology and behavior of Liogenys fuscus Blanchard (Insecta, Coleoptera, Scarabaeidae) in Aquidauana, Mato Grosso do Sul, Brazil. Rev. Bras. Entomol. 52(4):637-640. http://dx.doi.org/10.1590/ S0085-56262008000400015

RONQUI, D.C. \& LOPES, J. 2006. Composição e diversidade de Scrabaeoidea (Coleopera) atraídos por armadilha de luz em área rural no norte do Paraná, Brasil. Iheringia. 96(1):103-108. http://dx.doi.org/10.1590/ S0073-47212006000100018

SANTOS, V. \& ÁVILA, C.J. 2007. Aspectos bioecológicos de Cyclocephala forsteri Endrödi, 1963 (Coleoptera: Melolonthidae) no estado de Mato Grosso do Sul. Rev. Agric. 82:298-303.

SALVADORI, J.R. \& PEREIRA, P.R.V.S. 2006. Manejo integrado de corós em trigo e culturas associadas. Embrapa CNPT, Passo Fundo, 9p. Comunicado Técnico online, n. 203. Disponível em: http://www.cnpt. embrapa.br/biblio/co/p_co203.htm. Acesso em 01.12.2008.

SALVADORI, J.R. 1999. Manejo de corós em cereais de inverno. Comunicado Técnico online n. ${ }^{\circ}$ 3. Passo Fundo, Embrapa CNPT, 3p. http://www.cnpt. embrapa.br/biblio/p_co03.htm (ultimo acesso em 27/11/2008. 